\title{
E-procurement in public sector: a global overview
}

\section{Cevdet Bulut*}

23F Peak Road,

Cheung Chau, Hong Kong SAR, China

E-mail: cevdet@graduate.hku.hk

${ }^{*}$ Corresponding author

\section{Benjamin P-C. Yen}

School of Business,

The University of Hong Kong,

Pokfulam Road, Hong Kong SAR, China

E-mail: benyen@business.hku.hk

\begin{abstract}
This paper provides a global overview of both recent developments and current initiatives in public e-procurement. The Hong Kong Government's E-Procurement Pilot Programme will serve as a case study that will be discussed using a descriptive case study approach. A qualitative methodology is employed with findings that indicate that the development of public e-procurement is a matter of perception rather than other factors such as ITC infrastructure availability. E-procurement is underutilised in the public sector, where the majority of implemented systems are in the form of e-journal and e-tendering solutions. Concurrently, the findings also point to a growing trend in cross-border initiatives within public sectors where e-procurement is the driving force. The case study results suggest that the Hong Kong Government's initiative is successful especially in terms of political support, adaptation of suppliers and system design. This paper provides valuable insight into the potential role of public e-procurement initiatives.
\end{abstract}

Keywords: e-government; electronic procurement; public procurement; case study; e-tendering; e-catalogue; e-marketplace.

Reference to this paper should be made as follows: Bulut, C. and Yen, B.P-C. $(\mathrm{xxxx})$ 'E-procurement in public sector: a global overview', Electronic Government, an Int. J., Vol. x, No. x, pp.xxx-xxx.

Biographical notes: Cevdet Bulut is an IT professional based in Hong Kong. He received his BSc degree in Information Systems from the Vienna University of Economics and Business (2009) and his MSc degree (Distinction) in Electronic Commerce and Internet Computing from the University of Hong Kong (2010). His research interests are in the areas of e-commerce \& e-government, ERP and IT project management.

Benjamin P-C. Yen is an Associate Professor in the School of Business at the University of Hong Kong. He received his MS degree in Computer Science, MPhil and $\mathrm{PhD}$ degrees in Industrial Engineering and Operations Research from Columbia University. His research interests include e-commerce, electronic catalogues, IT-based supply chain management, web information retrieval and scheduling systems. 


\section{Introduction}

The motivation behind this research is to contribute to existing literature on public e-procurement and to provide valuable insight for researchers, policy makers and practitioners into future implementation of public e-procurement. E-procurement has tremendous potential for the public sector. However, it is not fully appreciated and has not been exploited within the public sector to the extent that it has been within the private sector. When compared to the private sector, limited research has been conducted on public e-procurement (Schoenherr and Tummala, 2007) and this existing research primarily focuses on the local or national level. Therefore, this paper attempts to answer the primary research question of where we stand today with public e-procurement. To this end, the main objective of this paper is to provide a global overview of both recent developments and current initiatives in public sector e-procurement. To contribute to answering the above-mentioned research question, we present a case study on one of the recent public e-procurement initiatives, namely, the E-Procurement Pilot Programme of the Government of Hong Kong Special Administrative Region (Hong Kong SAR). This includes a discussion of the strategic approach of the Hong Kong government and the implementation of the e-procurement initiative in addition to the Government's responses to the challenges that have been faced.

The rest of the paper is organised as follows: Section 2 describes the research methodologies. In Section 3, we briefly describe common e-procurement solutions implemented within the public sector and discuss driving forces for its adoption. Section 4 outlines the recent developments and current worldwide initiatives. In Section 5, we focus on the case study, which starts with a brief overview of e-procurement development, then describes the project in detail including objectives, implementation approach, challenges faced during the implementation and its first results. This section concludes with an assessment of the system coupled with some recommendations. In Section 6, the paper concludes with a summary of findings, managerial implications, limitations and directions for future research.

\section{Methodology}

A qualitative method is selected to understand the fundamentals of e-procurement concept and solutions applied in public sector. A rich qualitative resource was collected to find answers to what the main drivers and potential benefits are that inducing public sector organisations to adopt e-procurement and what the barriers and challenges are that public sector organisations often deal with. Data were collected mainly from literature, white papers, newspaper reports, annual reports, websites, surveys and existing case studies.

In the case study part, we used a descriptive case study approach to obtain an in-depth analysis of the design and implementing processes of e-procurement systems. We selected Hong Kong's Pilot Programme for the case study and focused on aspects, including the approach adopted by the Hong Kong Government in the implementation, the expected and realised benefits, the solution design and the funding model, as well as the challenges faced during the implementation and the Government's responses to them. Besides, an assessment of the implementation was carried out and some recommendations are made to enhance success of the implementation. 
Data analysed to form the case study were mainly derived from official documents (project documents, legal and policy documents, newsletters, presentations and user manuals) and links supplemented by interviews. A limited number of interviews with a government official, who has been involved in the implementation, were conducted over phone and via e-mail on the condition of confidentiality.

\section{E-procurement in public sector}

Organisations buy or sell products or services as a part of their nature. The advent of Internet and Communication Technology (ICT) has changed the way they procure and introduced a new term called e-procurement. At the beginning of 1990s the web-based procurement systems were in use for first time. Large corporations such as Cisco, Dell or IBM were the first pioneers and users of e-procurement systems (Trauth, 2001).

Although e-procurement was adopted by private sector first, it has drawn great attention within the public sector. Drivers for implementing e-procurement systems in public sector vary from one government to another. The main driver for many local and central governments in developed countries has been to reduce administration and transaction costs and to improve competition (especially promoting Small and Medium Enterprises (SMEs)). In contrast, in countries with high levels of corruption e-procurement is perceived as a weapon to combat corruption in public procurement. Public procurement accounts for about $20 \%$ of worldwide government expenditure. However, within some African countries this can amount to more than $70 \%$. Achieving a reduction in public spending by as little as $1 \%$ would make a significant difference and save a large amount of taxpayer's money (ADB/OECD, 2008; Knight et al., 2007; Basheka and Bisangabasaija, 2010).

As a result, a number of governments have launched or are in the planning stages of launching e-procurement systems as one of their main e-government initiatives. Although progress has been made, the integration of e-procurement technology into the public sector remains far from ideal. For the majority of public organisations, the process of implementing and adopting e-procurement systems is like any other IT system that presents challenges as a result of internal reasons such as organisational issues as well as external reasons such as lack of IT-infrastructure, skilled personnel and standardisation in addition to the related legal issues (Lindskog, 2008; Choudhari et al., 2011; Manoharan and Carrizales, 2011; Padhi and Mohapatra, 2011).

E-procurement solutions implemented within the public sector vary from the simplest form of electronic journal, web pages or portals that provide information on tender notices to more complex solutions such as e-tendering, e-catalogue (buyer-side), e-marketplace and e-auction (Schoenherr and Tummala, 2007; Bubeck and Fuchs, 2003). The e-catalogue, e-marketplace and e-auction solutions are established mechanisms within the private sector and are also finding a place within the public sector. Of these, the e-catalogue is one of the most commonly implemented e-procurement solutions. In contrast, e-auction and e-marketplaces are less commonly implemented within the public sector.

E-journal and e-tendering solutions are specifically designed to cater for the needs of the public sector. Public sector organisations use e-journals to provide information on tender notices instead of running advertisements in newspapers or gazettes. This strategy complies with the disclosure requirements for the awarding of major contracts as well as 
the advantage of saving costs typically spent on running newspaper advertisements. E-journal functions are severely limited and typically include providing the opportunity to view tender opportunities, ordering tender documents in paper format or the mechanism to download them directly from the webpage in electronic format (Bubeck and Fuchs, 2003). The e-journal is the most commonly implemented e-procurement solution within the public sector because it is easy to use and requires relatively few financial and technical resources.

On the other hand, e-tendering solutions are more complex and usually consist of various modules such as the designing of official internal processes (determining the awarding procedure and preparation of tender documents, etc.), an e-journal module for tender notices (including registration of bidders and shipping of the documents), a bidding module (preparing and bidding with an electronic signature) and finally an application that enables the storage, opening and evaluation of bids (Bubeck and Fuchs, 2003). Other e-procurement solutions are used to facilitate the acquisition of low-value and high-volume standard goods and services. However, e-tendering is a solution that is specifically designed to electronically manage the process of public tendering for the acquisition of specialised goods, works and consulting services that are of high value and low volume (World Bank, 2003). It is the second most implemented e-procurement solution within the public sector. However, some of the e-procurement systems that are currently implemented are described as e-tendering systems and this is not entirely accurate as they fulfil similar functions to an e-journal that only allow one-way transactions. For instance, suppliers can only download tendering documents and are unable to submit documents and/or bid for tenders using this system. Therefore, such systems can be classified as e-journal systems (see Table 1).

E-procurement solutions such as e-catalogues and e-marketplaces are designed with the primary purpose of serving the needs of businesses and were established within the private sector far earlier than the public sector. Therefore, these solutions would not necessarily cater for the particular needs of the public sector. This is because public and private sectors have different procurement objectives even though they share the same basic procurement goal in finding potential supplies to attain the lowest price at an acceptable quality level (Panayiotou et al., 2004). Public sector organisations are not concerned about competitive advantage or profitability but are expected to serve the taxpayer's interests by spending money in an efficient manner, managing budgets according to legislative and administrative orders and maintaining a system of checks and balances consistent with a policy of full disclosure and public review (Ulstrup, 2001). In contrast to private sector procurement, the public sector procurement processes are highly complex and bureaucratic due to the nature of the institutions and are usually bound by rules and regulations made by local, regional, national and international public organisations (Maniatopoulos, 2004).

\section{E-procurement initiatives in public sector around the world}

E-procurement is a growing trend within the public sector and is a driving force for e-government initiatives around the world. In recent years, many governments from all over the world at national or local level have launched e-procurement initiatives.

The first e-procurement initiative implemented within the public sector was the NASA Acquisition Internet Service in USA. NASA published first time tenders 
with a value between US\$25,000 and US\$500,000 at prod.nais.nasa.gov (Zarnekow et al., 2002). Today, at country-level, Chile, Guatemala, India, Italy, Panama, Philippines, Romania, South Korea and Thailand are considered to have the most advanced and successful public e-procurement systems (see Table 1).

At the regional level, the largest dedicated effort afforded to e-procurement was made by the European Union (EU) with its Pan-European Public Procurement Online (PEPPOL) project. This is currently a pilot implementation that is considered to be a unique example of its kind and represents a very valuable model for e-procurement initiatives at the regional level. When completed, any company within an EU member state will be able to communicate electronically with any other public agency within another EU member state for all procurement processes (PEPPOL, 2008).

At the global level, international organisations such as the World Bank, Asia Pacific Economic Cooperation (APEC), Asian Development Bank (ADB), Inter-American Development Bank (IDB) and African Development Bank (ADB) are actively promoting e-procurement within developing countries by providing financial support and guidance in implementing e-procurement.

Table 1 provides an overview of many e-procurement initiatives worldwide with some brief information. Due to the large number of implemented systems, the number that is included has been limited. Therefore, Table 1 includes a comprehensive list of implemented systems including e-journal solutions at national and an exceptional regional level system in the solitary case of the EU. The following table also includes initiatives at state level for selected countries. However, those that are only in the form of

Acronym 'ADB' has been used for both the terms 'Asian Development Bank' and 'African Development Bank'. Please clarify if this ok. e-journals have been excluded.

Table 1 E-procurement initiatives in public sector worldwide

\begin{tabular}{|c|c|c|c|c|c|c|c|}
\hline Country & Name & $J$ & $T$ & $C$ & $A$ & $\begin{array}{c}\text { Funding/ } \\
\text { M ownership }\end{array}$ & $\begin{array}{c}\text { No. of } \\
\text { buyers/suppliers* }\end{array}$ \\
\hline Afghanistan & ARDS & & $\checkmark$ & & & Public/public & - \\
\hline Albania & app.gov.al & & $\checkmark$ & & & Public/public & $-/ 109,369$ \\
\hline $\begin{array}{l}\text { Australia } \\
\text { (federal gov.) }\end{array}$ & AusTender & & $\checkmark$ & & & Public/public & - \\
\hline \multirow[t]{2}{*}{ NSW } & NSW eTendering & & & & & Public/public & $120 / 70,000$ \\
\hline & smartbuy ${ }^{\circledR}$ & & $\checkmark$ & & & $\checkmark$ Public/public & $800 / 12,600$ \\
\hline Queensland & QLD eTender & & $\checkmark$ & & & Public/public & - \\
\hline $\mathrm{SA}$ & SA Tend \& Contr. & & $\checkmark$ & & & Public/public & - \\
\hline Tasmania & TAS. Gov. Tend. & & $\checkmark$ & & & Public/public & - \\
\hline West Australia & GEM & & $\checkmark$ & & & Public/public & - \\
\hline Brazil & ComprasNet & & $\checkmark$ & $\checkmark$ & $\checkmark$ & Public/public & - \\
\hline \multirow{2}{*}{$\begin{array}{l}\text { Canada } \\
\text { (central gov.) }\end{array}$} & Contacts Canada & $\checkmark$ & & & & Public/public & - \\
\hline & MERX & & $\checkmark$ & & & Self/private & $15,000 / 50,000$ \\
\hline Alberta & AB Purch. Conn. & & $\checkmark$ & & & Self/public & - \\
\hline $\mathrm{BC}$ & BC Procurement & & $\checkmark$ & & $\checkmark$ & Self/public & - \\
\hline NB & NBON & & $\checkmark$ & & & Public/public & - \\
\hline
\end{tabular}


Table 1 E-procurement initiatives in public sector worldwide (continued)

\begin{tabular}{|c|c|c|c|c|c|c|c|}
\hline Country & Name & $J$ & $T$ & $C$ & $A$ & $\begin{array}{c}\text { Funding/ } \\
\text { M ownership }\end{array}$ & $\begin{array}{c}\text { No. of } \\
\text { buyers/suppliers* }\end{array}$ \\
\hline Chile & ChileCompra & $\checkmark$ & $\checkmark$ & $\checkmark$ & & Public/public & $900 / 100,000$ \\
\hline China & ccgp.gov.cn & $\checkmark$ & & & & Public/public & - \\
\hline Ecuador & Compras Públicas & & $\checkmark$ & $\checkmark$ & $\checkmark$ & $\checkmark$ Public/public & - \\
\hline Egypt & etenders.gov.eg & & $\checkmark$ & & & Public/public & - \\
\hline $\begin{array}{l}\text { European Union } \\
\text { (central) }\end{array}$ & Simap/Ted & $\checkmark$ & & & & Public/public & - \\
\hline \multirow[t]{2}{*}{ Austria } & auftrag.at & $\checkmark$ & & & & Self/private & - \\
\hline & BBG e-Shop & & & $\checkmark$ & & Public/public & 11,700 \\
\hline Belgium & publicprocurement.be & $\checkmark$ & $\checkmark$ & $\checkmark$ & $\checkmark$ & Public/public & - \\
\hline Cyprus & eprocurement.gov.cy & & $\checkmark$ & $\checkmark$ & & Public/public & - \\
\hline Czech Rep. & centralniadresa.cz & $\checkmark$ & & & & - & - \\
\hline \multirow[t]{2}{*}{ Denmark } & Evenex & & & $\checkmark$ & $\checkmark$ & $\checkmark$ Self/private & 4,000 \\
\hline & netindkoeb.dk & & & & $\checkmark$ & Public/public & $-/ 100$ \\
\hline Estonia & riigihanked.riik.ee & $\checkmark$ & $\checkmark$ & & $\checkmark$ & Public/public & - \\
\hline Finland & HILMA & $\checkmark$ & & & & Public/public & - \\
\hline France & Marches Publics & & $\checkmark$ & & & Public/public & - \\
\hline \multirow[t]{3}{*}{ Germany } & Bund.de & $\checkmark$ & & & & Public/public & - \\
\hline & e-Vergabe & & $\checkmark$ & & & Public/public & $-15 \%$ of sup. \\
\hline & Kaufhaus des Bund. & & & $\checkmark$ & & Public/public & $180 / 320$ \\
\hline Hungary & kozbeszerzes.hu & $\checkmark$ & & & & Public/public & - \\
\hline Ireland & etenders.gov.ie & & $\checkmark$ & & & Public/public & - \\
\hline Italy & Acquisti in Rete & & $\checkmark$ & $\checkmark$ & & $\checkmark$ Public/public & $4000 / 3000$ \\
\hline Latvia & eiepirkumi.gov.lv & & & $\checkmark$ & & Public/public & $382 / 89$ \\
\hline \multirow[t]{2}{*}{ Lithuania } & CVP IS & & $\checkmark$ & & & Public/public & - \\
\hline & cpo.lt & & & $\checkmark$ & & Public/public & $1295 / 82$ \\
\hline Luxembourg & marches.public.lu & $\checkmark$ & & & & Public/public & - \\
\hline \multirow[t]{2}{*}{ Norway } & doffin.no & $\checkmark$ & & & & Public/public & - \\
\hline & Ehandel.no & & & $\checkmark$ & & $\checkmark$ Self/public & $158 / 422$ \\
\hline Poland & portal.uzp.gov.pl & $\checkmark$ & & & & Public/public & - \\
\hline \multirow[t]{6}{*}{ Portugal } & vortalGOV & & $\checkmark$ & & & Self/private & $2018 / 20,124$ \\
\hline & acinGov & & $\checkmark$ & & & Self/private & - \\
\hline & Base.gov.pt & & $\checkmark$ & & & Self/private & - \\
\hline & ComprasPT & & $\checkmark$ & & & Self/private & - \\
\hline & Compras Públicas & & $\checkmark$ & & & Self/private & $-/ 20,000$ \\
\hline & anoGov & & $\checkmark$ & & & Self/private & - \\
\hline Romania & SEAP (eLicitatie) & $\checkmark$ & & $\checkmark$ & $\checkmark$ & Self/public & $13,436 / 42,946$ \\
\hline
\end{tabular}


Table 1 E-procurement initiatives in public sector worldwide (continued)

\begin{tabular}{|c|c|c|c|c|c|c|c|}
\hline Country & Name & $J$ & $T$ & $C$ & $A$ & $\begin{array}{c}\text { Funding/ } \\
\text { M ownership }\end{array}$ & $\begin{array}{c}\text { No. of } \\
\text { buyers/suppliers* }\end{array}$ \\
\hline Slovenia & enarocanje.si & $\checkmark$ & & & & Self/public & - \\
\hline \multirow[t]{2}{*}{ Spain } & catalogopatrimonio.meh.es & & $\checkmark$ & $\checkmark$ & & Public/public & $2200 / 350$ \\
\hline & contrataciondelestado.es & & $\checkmark$ & & & Public/public & - \\
\hline Sweden & avropa.nu & $\checkmark$ & & & & Public/public & - \\
\hline \multirow[t]{2}{*}{ UK } & Gov. Proc. Service & & $\checkmark$ & $\checkmark$ & $\checkmark$ & $\checkmark$ Self/public & $14,500 / 2000$ \\
\hline & Contracts Finder & $\checkmark$ & & & & Public/public & - \\
\hline Ghana & ppbghana.org & $\checkmark$ & & & & Public/public & - \\
\hline Guatemala & Guatecompras & & $\checkmark$ & $\checkmark$ & & $\checkmark$ Public/public & $937 / 2000$ \\
\hline \multirow[t]{2}{*}{ Hong Kong Sar } & e-Tender Box & & $\checkmark$ & & & Public/public & - \\
\hline & eProc. Pilot Prog. & & & $\checkmark$ & & $\checkmark$ Public/public & $3 / 2567$ \\
\hline $\begin{array}{l}\text { India } \\
\text { (central gov.) }\end{array}$ & tenders.gov.in & $\checkmark$ & & & & Public/public & - \\
\hline Andra Pradesh & eprocurement.gov.in & & $\checkmark$ & & $\checkmark$ & Public/public & - \\
\hline Karnataka & eproc.karnataka.gov.in & & $\checkmark$ & $\checkmark$ & $\checkmark$ & Self/public & $46 / 5500$ \\
\hline Indonesia & LPSE & & $\checkmark$ & & & Public/public & - \\
\hline Japan & JETRO & $\checkmark$ & & & & Public/public & - \\
\hline Jordan & gtd.gov.jo & $\checkmark$ & & & & Public/public & - \\
\hline Mongolia & e-procurement.mn & $\checkmark$ & & & & Public/public & - \\
\hline Morocco & marchespublics.gov.ma & $\checkmark$ & & & & Public/public & - \\
\hline New Zealand & GETS & $\checkmark$ & & & & Public/public & - \\
\hline Panama & PanamaCompra & & $\checkmark$ & $\checkmark$ & & $\checkmark$ Public/public & $137 / 15,000$ \\
\hline Pakistan & PPRA & & $\checkmark$ & & & Public/public & - \\
\hline Philippines & PhilGEPS & $\checkmark$ & & $\checkmark$ & & Public/public & $15,307 / 65,696$ \\
\hline \multirow{2}{*}{$\begin{array}{l}\text { Russia } \\
\text { (central gov.) }\end{array}$} & roseltorg.ru & & & & $\checkmark$ & - & $217,144 / 78,072$ \\
\hline & sberbank-ast.ru & & & & $\checkmark$ & -/public & - \\
\hline Tatarstan & zakazrf.ru & & & & $\checkmark$ & -/public & $2508 / 3383$ \\
\hline Singapore & GeBIZ & & $\checkmark$ & $\checkmark$ & $\checkmark$ & Self/public & - \\
\hline South Korea & KONEPS & $\checkmark$ & $\checkmark$ & $\checkmark$ & & $\checkmark$ Public/public & $37,000 / 120,000$ \\
\hline Sri Lanka & npa.gov.lk & $\checkmark$ & & & & Public/public & - \\
\hline Switzerland & simap.ch & $\checkmark$ & & & & Public/public & - \\
\hline Uganda & ppda.go.ug & $\checkmark$ & & & & Public/public & - \\
\hline $\begin{array}{l}\text { USA } \\
\text { (federal gov.)** }\end{array}$ & FedBizOpps & $\checkmark$ & & & & Public/public & - \\
\hline Arizona & ProcureAZ & & & $\checkmark$ & & Public/public & - \\
\hline California & eProcurement & $\checkmark$ & $\checkmark$ & $\checkmark$ & & Public/public & $189 / 65,000$ \\
\hline Florida & MFMP & & & $\checkmark$ & & Self/public & $32 / 149,000$ \\
\hline Georgia & TGM & & & & & $\checkmark$ Public/public & $75 / 31,052$ \\
\hline
\end{tabular}


Table 1 E-procurement initiatives in public sector worldwide (continued)

\begin{tabular}{|c|c|c|c|c|c|c|c|}
\hline Country & Name & $J$ & $T$ & $C$ & $A$ & $\begin{array}{c}\text { Funding/ } \\
\text { M ownership }\end{array}$ & $\begin{array}{c}\text { No. of } \\
\text { buyers/suppliers* }\end{array}$ \\
\hline Hawaii & HePS & & & & & $\checkmark$ Self/private & - \\
\hline Idaho & IPRO & & & & & $\checkmark$ Self/private & - \\
\hline Illinois & Sell 2 Illinois & & $\checkmark$ & & & Public/public & - \\
\hline Kentucky & eProcurement & & & $\checkmark$ & & Public/public & - \\
\hline Maryland & eMaryland Marketplc. & & & $\checkmark$ & $\checkmark$ & Public/public & $120 / 2600$ \\
\hline Massachusetts & Comm-Pass & & $\checkmark$ & & & Public/public & $399 / 2000$ \\
\hline Michigan & Bid4Michigan & & $\checkmark$ & & & Self/public & $386 /-$ \\
\hline Missouri & Online Bidding & & $\checkmark$ & & & Self/public & - \\
\hline North Carolina & NC E-Proc. & & & $\checkmark$ & & Self/public & $233 / 48,969$ \\
\hline Oregon & Orpin & & $\checkmark$ & & & Public/public & - \\
\hline South Carolina & SC Enterprise IS & & $\checkmark$ & & & Public/public & - \\
\hline Texas & TxSmartBuy & & & $\checkmark$ & & Self/public & $2000 / 146$ \\
\hline Virginia & eVA & & & $\checkmark$ & $\checkmark$ & Self/public & $746 / 53,094$ \\
\hline Thailand & gprocurement.go.th & & $\checkmark$ & $\checkmark$ & $\checkmark$ & $\checkmark$ Public/public & - \\
\hline Tunisia & marchespublics.gov.tn & $\checkmark$ & & & & Public/public & - \\
\hline Turkey & E-Ihale - dmo.gov.tr & $\checkmark$ & & $\checkmark$ & & Public/public & - \\
\hline
\end{tabular}

$\mathrm{J}=\mathrm{E}$-Journal, $\mathrm{T}=\mathrm{E}-\mathrm{Tender}, \mathrm{C}=\mathrm{E}-$ Catalogue, $\mathrm{A}=\mathrm{E}$-Auction, $\mathrm{M}=$ E-Marketplace.

*Figures are the most recent figures that have been made available on the respective websites and may not be actual.

**Figures given for e-procurement systems of the state governments are partly taken from NASPO (2009).

\section{Case study on E-Procurement Pilot Programme of Hong Kong SAR}

\subsection{Introduction and background}

The development of e-procurement in Hong Kong started in 1997 as part of the Digital 21 Strategy initiative that was launched under the leadership of Tung Chee Hwa, the first Chief Executive of Hong Kong.

In April 2000, the Government's first e-procurement system (an e-tendering system) was launched for the tendering of non-works projects that did not exceed HK\$10 million each. The Electronic Tendering System (ETS) is owned by the Government Logistics Department (GLD) and was implemented as a public-private partnership. ETS was both developed and operated by a third-party service provider and was the first e-tendering system to be implemented that supported a two-way true transaction process that allows online tender posting and submission (ITBB, 2001).

In January 2010, the GLD replaced the ETS with a new e-tendering system that was named e-Tender Box (ETB). ETB, which can be found at gldetb.gov.hk, is integrated with GLD's existing Procurement and Contract Management System (PCMS). The system is wholly funded by the government and allows suppliers to download tender 
documents, submit tender offers, make tender enquiries and view tender notices as well as contract award notices at no cost (GLD, 2010a, 2010b).

In 2001, the government revised the Digital 21 Strategy by publishing a second edition in which e-procurement was highlighted as an integral part of the e-government strategy (ITBB, 2001). This highlighted the government's commitment to actively implementing and driving e-procurement initiatives. Some initial positive results that were achieved through the e-tendering system were instrumental in convincing the government to adopt an e-procurement approach for the entire government procurement process and to implement an additional e-procurement system for high-volume and low-value items.

\subsection{The project}

Public procurement in Hong Kong is predominantly conducted in a decentralised manner by individual government departments. Procurement of high-value goods and services is processed using either paper-based methods or online through the e-tendering system: ETB. However, the procurement of low-value products and non-construction services accounts for over $99 \%$ of purchase orders and $30 \%$ of purchase value (FSTB, 2011). These procurement arrangements were largely paper-based and conducted through manual processes. The handling of such volume of low-value procurement by government departments that are limited in their operational capacity has inevitably resulted in the public procurement process being labour-intensive, time-consuming, erroneous, inefficient and costly.

To deal with these issues and streamline low-value procurement within departments, the government considered leveraging e-procurement and proceeded to commission two consultancy studies in 2005 and 2006 to exploit the potential benefits of e-procurement for the public sector. Positive results gathered from these studies combined with successful examples from other governments in addition to the positive results and experience achieved from the implementation of the ETS encouraged the government to implement another e-procurement initiative.

In December 2006, the Office of the Government Chief Information Officer (OGCIO) with support from the Secretary for Commerce, Industry and Technology proposed a pilot e-procurement initiative for low-value purchases within government departments (Legislative Council, 2007). The Finance Committee started the implementation with funding approval in 2007. The system was then introduced in three pilot departments in June 2008 (Legislative Council, 2009).

\subsubsection{Objectives and expected benefits}

It is expected that implementation of the e-procurement initiative will bring various tangible and intangible benefits to both the government and suppliers. The primary objectives of the e-procurement initiative are to automate and integrate procurement processes as well as to enhance transparency, efficiency and cost-effectiveness in public procurement. Given the large number of suppliers interested and involved in public procurement, the government aims to encourage the adoption of IT and e-commerce practices among local suppliers, particularly SMEs, and thereby enhancing their competitiveness within a business environment that places increasing emphasis on efficient and quality services (Legislative Council, 2006). 


\subsubsection{Major functionalities}

The E-Procurement Pilot Programme (www.eprocurement.gov.hk) allows participating governmental departments and suppliers to conduct electronic and binding transactions over the web. As illustrated in Figure 1, when completed, the proposed e-procurement initiative will offer the following major functions, which have been progressively implemented since January 2008 (Legislative Council, 2006):

- $\quad$ procurement portal (encompassing intranet and supplier portal)

- internal workflow system

- e-sourcing

- e-catalogue

- $\quad$ spend analysis

- $\quad$ supplier performance.

Figure 1 The conceptual design of E-Procurement Pilot Programme (see online version for colours)

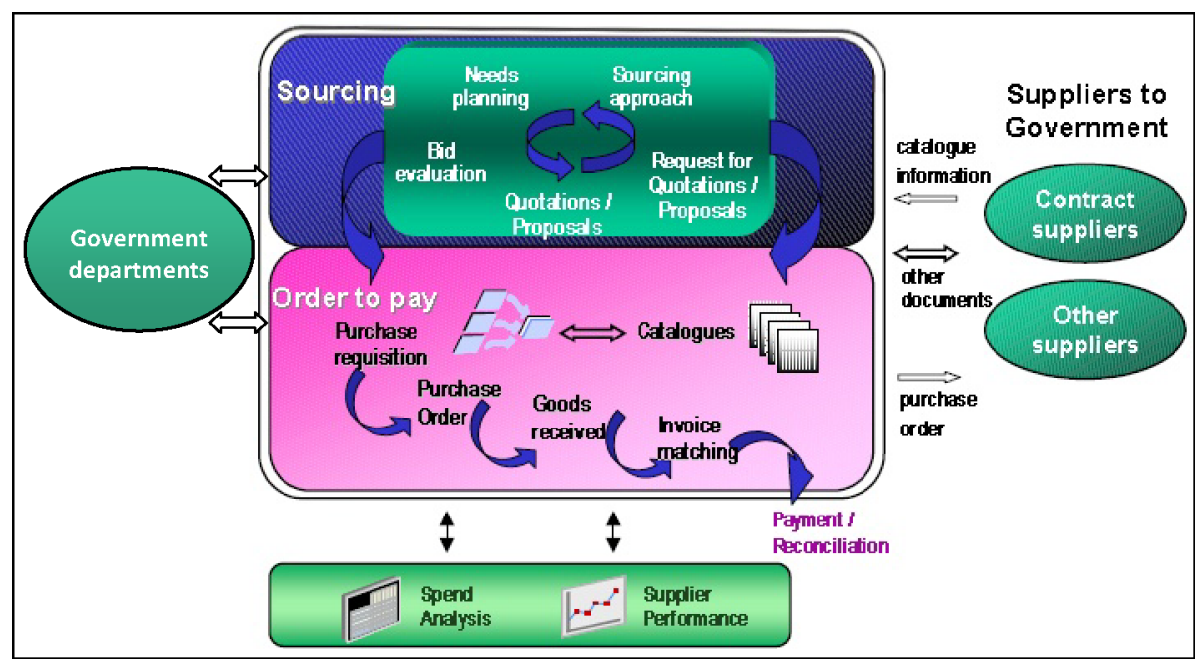

Source: Legislative Council (2006)

\subsubsection{Cost and funding}

The E-Procurement Pilot Programme is an example of a public-funding model. Stable funding has been secured due to resources made available through the e-government initiatives that form part of the Digital 21 Strategy. Initial costs of implementation and recurring costs for operation and maintenance of the system during the pilot stage are completely funded by the government. However, in order to finance future costs for operating and maintenance of the system, the government is considering an alternative funding model in the post-implementation review (Legislative Council, 2007). 
In keeping with the government's outsourcing policy that has been adhered to since 1999 , the implementation of the system is achieved through outsourcing, as is the case with most other government IT projects (OGCIO, 2011). The total cost of implementing the system (development, operation and consulting costs) between 2007 and 2011 is estimated to be HK\$49.2 million (US\$6.3 million) (Legislative Council, 2007). Table 2 provides a breakdown of the implementation cost.

Table 2 Estimated implementation costs

\begin{tabular}{lccccc}
\hline Costs (HK\$ million) & 2007-2008 & 2008-2009 & 2009-2010 & 2009-2011 & Total \\
\hline Hardware & 0.9 & 4.0 & 1.8 & 1.6 & 8.3 \\
Software and development & 1.3 & 5.3 & 2.2 & 1.3 & 10.1 \\
Implementation services & 2.2 & 2.6 & 5.1 & 2.7 & 12.6 \\
Contract staff & 5.4 & 5.6 & 4.9 & - & 15.9 \\
Contingency & 0.4 & 0.8 & 0.8 & 0.3 & 2.3 \\
\hline Total & 10.2 & 18.3 & 14.8 & 5.9 & 49.2 \\
\hline
\end{tabular}

Source: Legislative Council (2007)

\subsubsection{Organisation}

The E-Procurement Pilot Programme is owned and managed by the OGCIO that was established in July 2004 with responsibility for formulating and executing e-government policy in Hong Kong. The strong leadership of the government provided by the former Chief Executive of the Government, Tung Chee Hwa, initiated an institutional leadership that was succeeded by the OGCIO to ensure the sustainable development of e-government and e-procurement initiatives in Hong Kong.

\subsection{Implementation}

The government adopted a pilot approach and planned to implement the e-procurement system in an incremental manner with the intention of minimising project risks and to facilitate the transformational process from traditional procurement to e-procurement. A pilot approach would have additional benefits of enabling the government to verify estimated costs and potential rewards of the implementation. Operational issues identified during the pilot stage could prove useful to the government in mapping the way forward and extending the pilot initiative to other government departments (Legislative Council, 2007).

The Finance Committee launched the implementation of the e-procurement initiative in 2007 with funding approval that was followed by the system being introduced within the following pilot departments in June 2008:

- The Office of the Government Chief Information Officer (OGCIO)

- The Immigration Department (ImmD)

- The Environmental Protection Department (EPD). 
The incremental implementation of the system commenced in January 2008 with a target completion date of June 2009 (Legislative Council, 2006). During the first phase, the Intranet portal of the system was launched for sharing of procurement-related information such as green procurement between government employees on an internal basis (ImmD, 2008). In June 2008, the external portal (www.eprocurement.gov.hk) was launched for suppliers (ImmD, 2009). The majority of system functions were implemented during the second phase. The functions that were implemented between September 2009 and March 2010 are as follows (OGCIO, 2009):

- supplier inclusion

- account activation

- account management

- invitation of quotation

- purchase order

- e-catalogue

- e-submission.

Figure 2 Intranet portal of the E-Procurement Pilot Programme (see online version for colours)

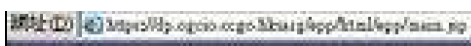

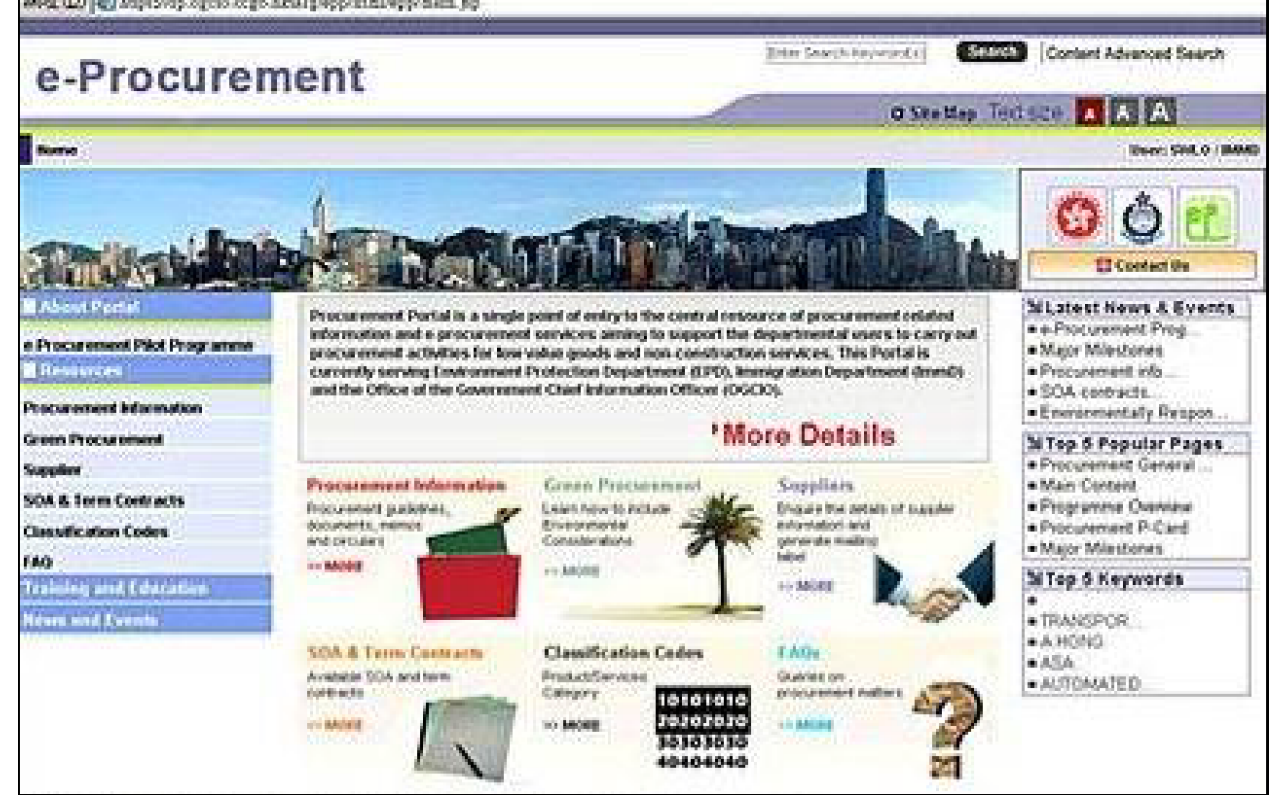

Author: Please cite Figures 2 and 3 in text.

Author: Please supply better quality figure for Figure 2.

Source: ImmD (2008)

\subsubsection{Technical and legal infrastructures}

Prior to the implementation of the E-Procurement Pilot Programme, the technical and legal infrastructures were already established in 1998. These are required for e-procurement and other e-government services and were primary objectives of the 
Digital 21 Strategy. At the same time, a strong ICT backbone was also developed through the liberalisation of the telecommunications sector and significant private sector investment (OGCIO, 2007).

In terms of required legal framework, the Electronic Transactions Ordinance (ETO) was enacted in January 2000 and is based upon the United Nations Commission on International Trade Law (UNCITRAL) for e-commerce. Therefore, digital signatures and electronic records attained the same legal status as that of their paper-based counterparts. Furthermore, a local Public Key Infrastructure (Hong Kong Post PKI) was developed and a certification authority (Hong Kong Post) was established to support the conduct of secure electronic transactions for the first time (ITBB, 1998).

Figure 3 Supplier portal of the E-Procurement Pilot Programme (see online version for colours)

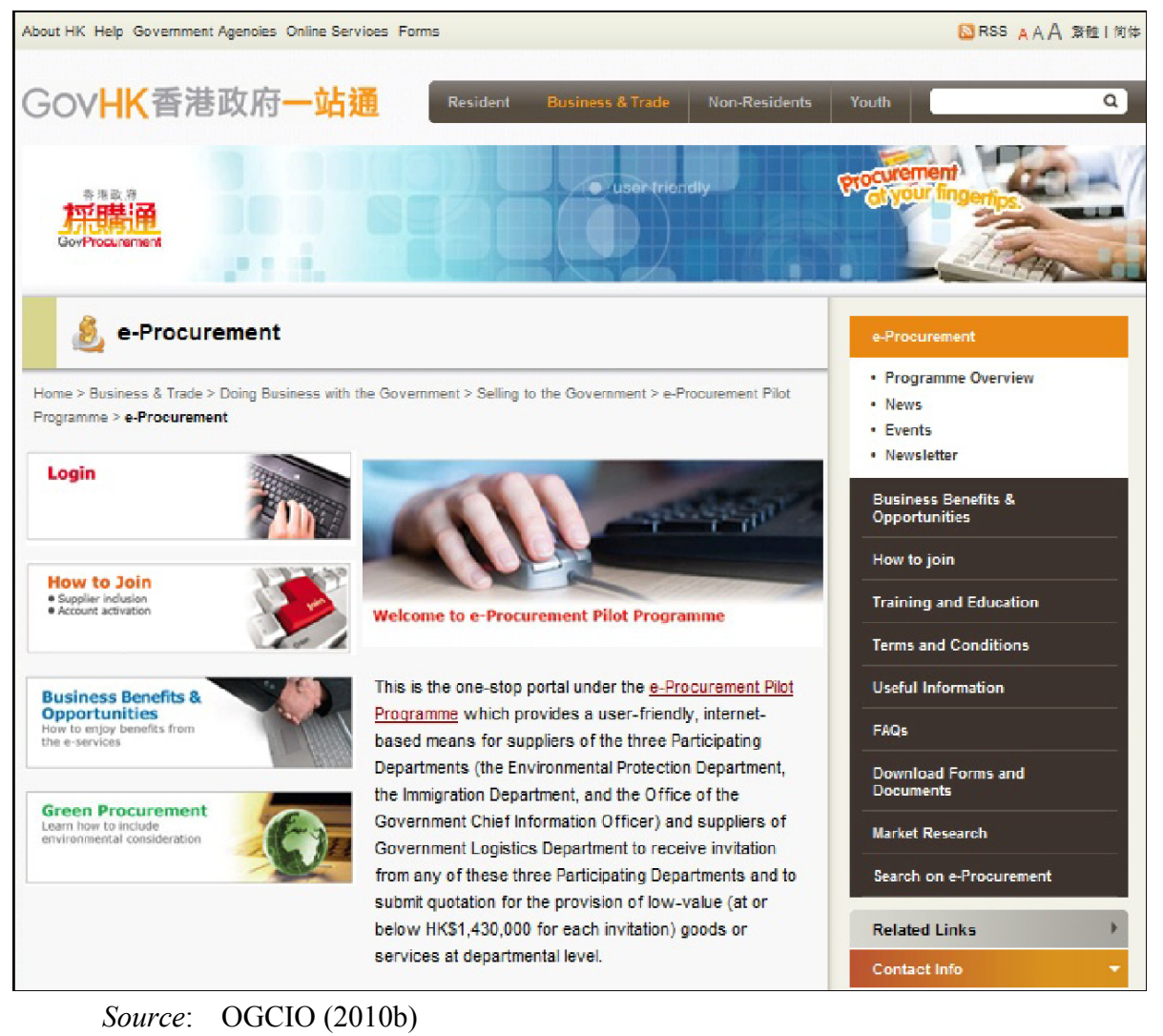

\subsubsection{System design}

The system is designed in line with the E-Government Interoperability Framework (IF) and E-Government Infrastructure Service (EGIS) in order to ensure interoperability between different back-office systems and standards used by government departments and suppliers. The system uses international open standards such as the Extensible Mark-up Language (XML) for data representation and exchange in addition to adopting the United Nations Standard for Product and Services Code (UNSPSC) for commodity classification. This can then be integrated with government department back-office 
systems. At present, the system provides interfaces to the treasury accounting systems and the GLD.

The system uses industry-standard security measures and complies with government security guidelines and authentication framework. Using appropriate measures such as Secure Socket Layer (SSL) and Public Key Infrastructure (PKI), storage and transmission of information from the user to the system are encrypted, protected and controlled according to the prescribed guidelines and procedures. To ensure security and integrity, an independent third-party regularly controls the system.

To avoid discouragement and to maximise usage of the e-procurement system among SMEs, the use of digital certificates is made optional. Suppliers, who prefer to use digital certificates, can access to the system, authenticate themselves and have full use of all functions by using their digital certificates. Digital certificates can be obtained from two recognised certification authorities, namely, the Hong Kong Post and Digi-Sign. Other suppliers, who either cannot afford or prefer not to use digital certificates, are required to use both a user ID and password that is assigned to them in order to gain access to the system. Suppliers can only use limited functions of the system by choosing to access with user ID and password. Limited functions include being able to update their profiles. In order to be able to participate in the bidding process, these suppliers are provided with a unique secret code that can only be used once. This code is generated randomly by the system and associated with the supplier's user profile that enables them to sign, accept and encrypt data (see Figure 4).

Figure 4 Invitation to quotation (see online version for colours)

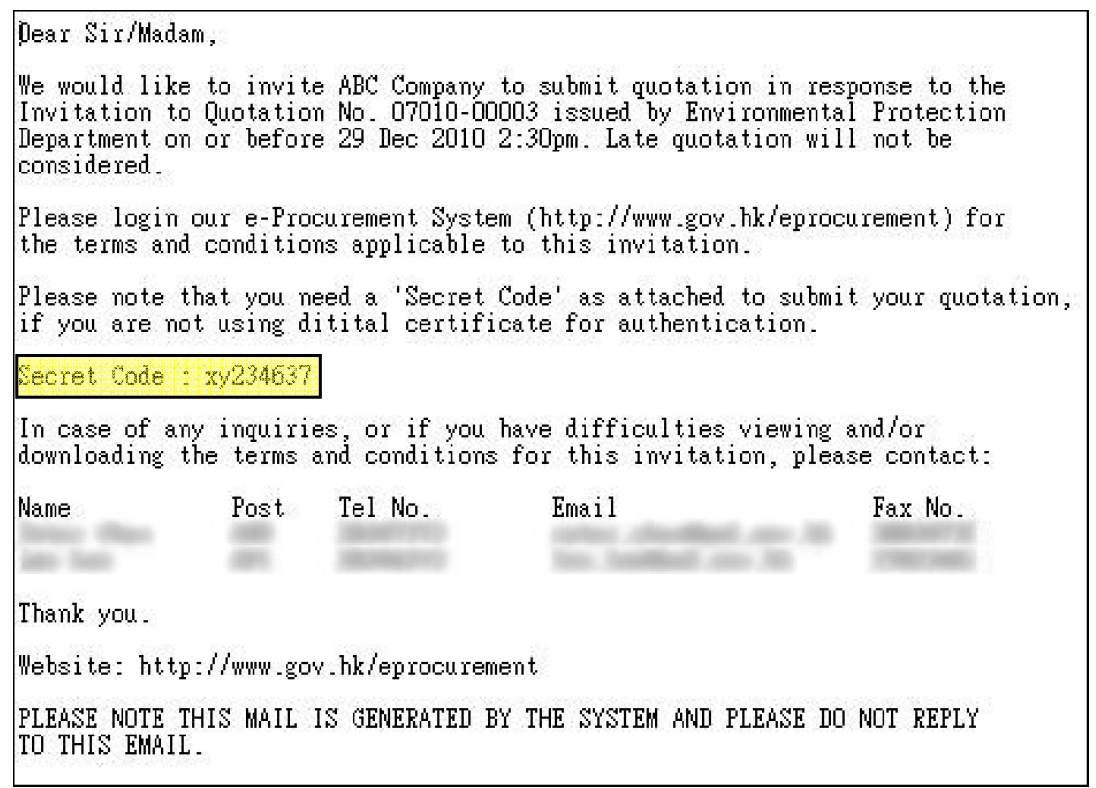

Source: OGCIO (2010a)

Quotations from suppliers can only be accessed and viewed by authorised persons within the government department. Suppliers are responsible for the protection and security of their own data (user ID/password and secret codes) to ensure security and to minimise the risk of security being compromised. It is also the responsibility of suppliers to ensure that 
submitted documents are virus-free. The system still checks all uploaded documents for viruses or any other malware and in the event that a quotation offer or document is found to contain a virus or malware, the system rejects the quotation offer, treats the offer as invalid and does not process it further (OGCIO, 2010c).

\subsection{Benefits realised}

The implementation of the e-procurement system is still in the pilot phase and has not been completed yet. Therefore, there is very limited information about the outcome of the implementation. Even though it is too early to determine whether expected benefits have been achieved, some tangible results are already apparent. As of March $4^{\text {th }} 2010$, the pilot departments issued 4362 purchase orders through the e-procurement system with a total value of approximately HK\$244 million (CEDB, 2010). When fully launched, it is estimated that 24,000 purchases will be processed through the system each year. This will result in annual savings of up to HK\$2 million within the pilot departments (Computerworld, 2009; Legislative Council, 2007).

Participation and interest in the e-procurement initiative from existing suppliers is quite high. As of February 2010, 2567 existing government suppliers (75.28\%) opted to register with the system. Initial experience of suppliers with the e-procurement initiative is also generally positive. In a survey conducted by the OGCIO in March 2010, 74.29\% ( $n=1907)$ of participating suppliers indicated that using e-procurement system could enhance their effectiveness and efficiency. Furthermore, all suppliers who participated in the survey found the system easy to use (CEDB, 2010; OGCIO, 2010d).

\subsection{Challenges}

The most significant challenges faced during the implementation of the E-Procurement Pilot Programme were reported as being change management and adaptation by government departments and suppliers. Since the migration to e-procurement is a major transformation process involving a large number of users and suppliers, its implementation requires significant changes for all stakeholders. In order to achieve a smooth transition from paper-based to e-procurement, better change management and to minimise the risks involved, a pilot approach and an incremental implementation strategy is employed. In addition to this, a stakeholder engagement programme was undertaken. This included seminars, workshops and trainings that aimed to increase awareness and to encourage the participation of both government employees and suppliers.

The adaptation of SMEs was another significant challenge. SMEs are extremely important to the Hong Kong economy due to the fact that they constitute over $98 \%$ of Hong Kong's business establishments, which collectively employ around $48 \%$ of the private sector workforce (GovHK, 2011). Encouraging the adoption of e-procurement among SMEs with the aim of enhancing their competitiveness is one of the project's primary objectives. Suppliers are engaged incrementally on a sector-by-sector basis according to their e-readiness. To avoid unfair competition by putting SMEs at a competitive disadvantage with other suppliers, both the manual and electronic modes of operation are kept in parallel during the pilot implementation.

The system is designed to be as simple as possible with minimum software and hardware requirements to make it accessible and affordable to SMEs. This explains why 
the proposed e-invoice module is excluded from the implementation and not covered in the scope of the pilot programme.

\subsection{Assessment and recommendations}

As there is currently very limited available information about the outcome of the implementation, it is difficult to make any serious assessment of the E-Procurement Pilot Programme. Nevertheless, there are still some conclusions that can be made about the implementation. Despite some negative findings, the overall impression of the E-Procurement Pilot Programme is positive (see Table 3 for detailed assessment).

There is no doubt that the pre-existence of Hong Kong's strong ICT infrastructure and legal framework was an advantage for the start-up of the implementation. The most important underlying factor for the successful implementation is the strong political and institutional support, which we believe will ensure sustainable ongoing development of the initiative.

In terms of appropriate system design, the implementation is quite successful. The system is carefully designed so that suppliers are not discouraged. For example, use of a one-time secret code as an option in addition to digital certificates has proven to be a great solution. Furthermore, unrestricted and equal access, use at no cost and user-friendly interface are other characteristics of the system that have also been of benefit. However, the system does not currently provide interface or integration to the ETB that is operated by the GLD. The suppliers registered with the E-Procurement Pilot Programme must also register separately with the ETB if they would like to participate in e-tendering processes. Co-existence of the ETB hinders the E-Procurement Pilot Programme to act as a single window for all e-procurement activities. Therefore, it is recommended that an interface from the system to ETB that allows single log-on between two e-procurement systems should be considered. However, it is proposed that a better solution would be to unify both systems by disestablishing ETB and covering e-tendering under the e-procurement system. This would also stop public money being wasted due to duplicating costs of development and maintenance.

To ensure interoperability and integration, the system uses the international open standards such as XML and UNSPSC. It also provides interfaces to back-office systems of government departments. However, the integration to back-office systems of suppliers has so far been ignored. The reason given for not providing integration for suppliers was the low use of back-office systems such as accounting and financial systems among suppliers in Hong Kong. Based on this reason the proposed e-invoice module is also excluded from the implementation. However, this argument contradicts the government's objective of encouraging the adoption of IT and e-commerce practices among local suppliers with the e-procurement initiative. On the contrary, providing system integration as an option for suppliers would indeed serve this objective in the long term. It is argued that this feature would induce suppliers to install back-office systems and integrate these with the e-procurement system of the government in order to be able to fully benefit from it. Therefore, it is recommended that the functions of the system be extended with e-payment and e-invoice modules and not only to provide integration for government departments but also for suppliers. Furthermore, in order to promote participation of new suppliers, an awareness campaign should be launched to convey the benefits of e-procurement. 
Table 3 Assessment of the E-Procurement Pilot Programme

\begin{tabular}{|c|c|c|c|c|}
\hline Criteria & $\begin{array}{l}\text { Not } \\
\text { fulfilled/largel } \\
\text { not fulfilled }\end{array}$ & $\begin{array}{r}\text { Partially } \\
\text { fulfilled }\end{array}$ & $\begin{array}{l}\text { lfilled/lars } \\
\text { fulfilled }\end{array}$ & Comment \\
\hline $\begin{array}{l}\text { Strong and consistent } \\
\text { leadership }\end{array}$ & & & $\mathrm{X}$ & $\begin{array}{l}\text { Strong political will and } \\
\text { leadership is consolidated with an } \\
\text { institutional leadership and taken } \\
\text { over by the OGCIO }\end{array}$ \\
\hline $\begin{array}{l}\text { Stakeholders } \\
\text { involvement }\end{array}$ & & N/A & & - \\
\hline $\begin{array}{l}\text { Complies with } \\
\text { procurement policies } \\
\text { and regulation }\end{array}$ & & & $X$ & $\begin{array}{l}\text { Complies with related laws and } \\
\text { regulations such as WTO GPA, } \\
\text { the Stores and Procurement } \\
\text { Regulations, the Personal Data } \\
\text { Ordinance and the Copyright } \\
\text { Ordinance }\end{array}$ \\
\hline $\begin{array}{l}\text { Encouraging user } \\
\text { participation }\end{array}$ & & $\mathrm{X}$ & & $\begin{array}{l}\text { More than } 90 \% \text { of existing } \\
\text { suppliers adopted the use } \\
\text { of e-procurement system. } \\
\text { However, no information } \\
\text { available about the participation } \\
\text { of new suppliers }\end{array}$ \\
\hline Training & & & $\mathrm{X}$ & $\begin{array}{l}\text { Training, Seminars and } \\
\text { Workshops are provided to both } \\
\text { the government employees and } \\
\text { suppliers }\end{array}$ \\
\hline Mandated use & $X$ & & & $\begin{array}{l}\text { No intension to mandate the } \\
\text { system }\end{array}$ \\
\hline Open access & & & $X$ & $\begin{array}{l}\text { No pre-condition. The system is } \\
\text { open to all suppliers including } \\
\text { SMEs }\end{array}$ \\
\hline $\begin{array}{l}\text { Access and use with } \\
\text { minimum technical } \\
\text { requirements }\end{array}$ & & & $\mathrm{X}$ & $\begin{array}{l}\text { Access using user ID and } \\
\text { password. The use of digital } \\
\text { certificates is optional, not } \\
\text { required }\end{array}$ \\
\hline $\begin{array}{l}\text { One-time registration } \\
\text { and single log-on } \\
\text { between e- } \\
\text { procurement systems }\end{array}$ & $X$ & & & $\begin{array}{l}\text { The system currently has no } \\
\text { interface to e-tendering system (E- } \\
\text { Tender Box) }\end{array}$ \\
\hline $\begin{array}{l}\text { Free to use }- \text { no fees } \\
\text { for common functions } \\
\text { and download of } \\
\text { standard documents }\end{array}$ & & & $\mathrm{X}$ & $\begin{array}{l}\text { The system is free for suppliers to } \\
\text { use }\end{array}$ \\
\hline $\begin{array}{l}\text { Documents readable } \\
\text { using standard } \\
\text { electronic formats }\end{array}$ & & & $\mathrm{X}$ & $\begin{array}{l}\text { PDF, DOC and XLS are used as } \\
\text { standard formats }\end{array}$ \\
\hline $\begin{array}{l}\text { Easy to use/ } \\
\text { User-friendly } \\
\text { graphical user } \\
\text { interface }\end{array}$ & & & $\mathrm{X}$ & $\begin{array}{l}\text { All suppliers find the system very } \\
\text { easy to use according to a survey }\end{array}$ \\
\hline Support & & & $\mathrm{X}$ & Hotline and Online FAQ provided \\
\hline
\end{tabular}


Table 3 Assessment of the E-Procurement Pilot Programme (continued)

\begin{tabular}{|c|c|c|c|}
\hline Criteria & $\begin{array}{l}\text { Not } \\
\text { fulfilled/largely Partially } \\
\text { not fulfilled fulfilled }\end{array}$ & $\begin{array}{l}\text { filled/larg } \\
\text { fulfilled }\end{array}$ & Comment \\
\hline Interoperability & & \multirow[b]{2}{*}{$\mathrm{X}$} & $\begin{array}{l}\text { The use of international open } \\
\text { standards such as XML and } \\
\text { UNSPSC etc. in line with IF and } \\
\text { EGIS }\end{array}$ \\
\hline $\begin{array}{l}\text { Integration with } \\
\text { backend office } \\
\text { systems }\end{array}$ & $\mathrm{X}$ & & $\begin{array}{l}\text { Integration is provided for } \\
\text { government departments, but not } \\
\text { for suppliers }\end{array}$ \\
\hline Security measures & & $\mathrm{X}$ & $\begin{array}{l}\text { The use of PKI, Digital } \\
\text { Certificates or One-Time Secret } \\
\text { Codes, Firewall and Security } \\
\text { Audit through independent third- } \\
\text { party }\end{array}$ \\
\hline $\begin{array}{l}\text { Transactions are } \\
\text { traceable and } \\
\text { auditable }\end{array}$ & & $\mathrm{X}$ & $\begin{array}{l}\text { Supplier performance module } \\
\text { allows to track, to assess and } \\
\text { analyses performance of suppliers } \\
\text { for the continuous improvement } \\
\text { of the service of suppliers }\end{array}$ \\
\hline
\end{tabular}

\section{Conclusion}

\subsection{Findings and managerial implications}

In conclusion, the findings of this study indicate that e-procurement is not appreciated and not exploited within the public sector to the same degree as it is within the private sector. The majority of implemented e-procurement systems within the public sector are in the form of e-journals or e-tendering solutions that offer limited functions.

Moreover, we found that the level of development of e-procurement within the public sector does not necessarily correlate with the level of development of these countries. As we can see from Table 1, the e-procurement initiatives of some of developing countries such as India, Romania, Guatemala, Panama, Thailand and the Philippines are obviously more advanced than those of some prosperous countries. We can therefore conclude that development of e-procurement within the public sector is really a matter of perception rather than issues such as availability of strong ITC infrastructure and financial resources although they play an important role. This finding corroborates previous studies by Kim (2007) and Gulati and Yates (2011), who found out that government effectiveness is much more important than any other factors in determining global e-government performance.

In light of these findings, it is recommended that governments do not ignore e-procurement but instead embrace and take full advantage of it. We urge policy makers to make strong commitments to implement and drive e-procurement initiatives. It is indeed the duty of governments to seek the means to provide public services in an efficient and cost-effective manner. 
The case study of the E-Procurement Pilot Programme of the Hong Kong Government provides valuable insights for policy makers and practitioners on how to make a public e-procurement initiative successful. Our assessment of the pilot programme indicates that the implementation has been successful, particularly, in terms of political and institutional support, participation and adaptation of existing suppliers in addition to the fact that the e-procurement system design uses international open standards to ensure interoperability and integration. Of particular importance is the solution that the Hong Kong Government devised to address the security vs. usability challenge, namely, the use of a one-time secret code as an option in addition to digital certificates.

The findings of this paper suggest that the perception of e-procurement among decision makers and other key stakeholders in addition to political and institutional support are prerequisites for e-procurement implementations and yet are not the only factors that lead to success. A holistic approach which addresses many issues that includes, but not limited to, creating the required legal framework and technical infrastructure, the selection of appropriate e-procurement solution and system design, the selection of a suitable funding model, and promoting awareness and encouraging participation of users for the implementation to be successful.

Despite its slow pace, there is no doubt that e-procurement will play an increasingly important role within the public sector. Presently, main issues such as security, standardisation and interoperability still remain as major obstacles that not only hinder the development of e-procurement but also the development of the e-commerce sector as a whole. Nevertheless, some notable improvements have been made in this regard as decision makers increasingly address these issues. Recent developments for common and widely accepted legal and technical standards turned the concept of cross-border public e-procurement between countries from imagination into feasible reality. The PEPPOL project of the EU is an excellent example in this regard. In the future, there may be more cross-border e-procurement initiatives such as those between countries of free trade areas such as the North American Free Trade Agreement (NAFTA) and Association of Southeast Asian Nations (ASEAN).

\subsection{Limitations and directions for future research}

There are several limitations to this paper that attempts to provide a global overview of recent developments and current initiatives in public e-procurement. Fundamentals of the public e-procurement concept and models, a detailed analysis of drivers and potential benefits as well as barriers and challenges that the public sector organisations are expected to deal with are not provided. Table 1 provides an overview of many existing initiatives that is drawn from very limited information. Furthermore, due to high number of implemented systems, we had to limit the number of those included. Therefore, a list of the implemented systems including e-journal solutions at national and exceptionally regional level in the case of the EU is included. This list can be further expanded to include initiatives at local level including all form of implemented e-procurement solutions to provide a better overview in countries where public procurement is highly decentralised and managed separately by local governments. It is also suggested that a continued review of initiatives is needed as new initiatives are implemented or as some of the existing initiatives are phased out. Future work can take a step further to enhance this research by conducting a detailed cross-country comparison with selected initiatives of 
various countries from different regions to cover a range of geographical locations, level of development and political systems.

The case study also has some limitations that should be addressed. The primary limitation is its descriptive nature. Data were mainly derived from official documents. A limited number of interviews with a government official, who has been involved in the implementation, were conducted over phone and via e-mail on the condition of confidentiality. Another consideration is that the initiative is still under pilot implementation and so information is still limited about the outcome of the implementation. Therefore, generalisability of the findings and full assessment of its validity might be limited. Since the implementation is still underway, a continued review and re-assessment of results is needed. Furthermore, it would also be interesting for future research to investigate whether this system could serve as a model for future e-procurement initiatives in countries with similar characteristics.

\section{References}

$\mathrm{ADB} / \mathrm{OECD}$ (2008) 'ADB/OECD anti-corruption initiative for Asia and the pacific: fighting bribery in public procurement in Asia and the Pacific', 7th Regional Seminar on Making International Anti-Corruption Standards Operational, OECD Publishing, Bali, Indonesia.

Basheka, B.C. and Bisangabasaija, E. (2010) 'Determinants of unethical public procurement in local government systems of Uganda: a case study', Int. J. Procurement Management, Vol. 3, No. 1, pp.91-104.

Bubeck, B. and Fuchs, G. (2003) 'Strukturwandel der Verwaltung und e-Government - Das Fallbeispiel der elektronischen elektronischen Beschaffung und Vergabe', in Bubeck, B. and Fuchs, G. (Eds.): Strukturwandel der Verwaltung und e-Government - Das Fallbeispiel der elektronischen elektronischen Beschaffung und Vergabe, TA-Akademie, Informationsgesellschaft, Stuttgart, pp.1-27.

CEDB (2010) Replies to Initial Written Questions Raised by Finance Committee Members in Examining the Estimates of Expenditure 2010-11, Question Serial No.2685, Reply Serial No.CEDB(CT)115, Commerce and Economic Development Bureau, Hong Kong, Available at http://www.legco.gov.hk/yr09-10/english/fc/fc/w_q/cedb-ct-e.pdf (Accessed April 1, 2012).

Choudhari, R.D., Banwet, D.K. and Gupta, M.P. (2011) 'Assessment of risk in e-governance projects: an application of product moment correlation and cluster analysis techniques', Electronic Government, An International Journal, Vol. 8, No. 1, pp.85-102.

Computerworld (2009) Hong Kong Government launches E-Procurement Pilot Program, Computerworld, Hong Kong, Available at http://cw.com.hk/news/hong-kong-governmentlaunches-e-procurement-pilot-program (Accessed April 1, 2012).

FSTB (2011) Guide to Procurement, Financial Services and the Treasury Bureau, Available at http://www.fstb.gov.hk/tb/eng/procurement/tender04.html (Accessed April 1, 2012).

GLD (2010a) E-Tender Box (ETB): What's New, Government Logistics Department, Available at https://www.gldpcms.gov.hk/portal/page/portal/PCMS/eng/Whats_new (Accessed April 1, 2012).

GLD (2010b) E-Tender Box (ETB): FAQ, Government Logistics Department, Available at https://www.gldpcms.gov.hk/portal/page/portal/PCMS/eng/FAQ (Accessed April 1, 2012).

GovHK (2011) Hong Kong Fact Sheets: Trade and Industry, Information Services Department of Hong Kong SARG, Available at http://www.gov.hk/en/about/abouthk/factsheets/docs/ trade\&industry.pdf (Accessed April 1, 2012).

Gulati, G.J. and Yates, D.J. (2011) 'Strategy, competition and investment: explaining the global divide in e-government implementation with policy variables', Electronic Government, An International Journal, Vol. 8, Nos. 2-3, pp.124-143. 
ImmD (2008) Immigration Department Annual Report 2007-2008, Immigration Department, Hong Kong, Available at http://www.immd.gov.hk/a_report_07-08/eng/chapter07/index.htm (Accessed April 1, 2012).

ImmD (2009) Immigration Department Annual Report 2008-2009, Immigration Department, Hong Kong, Available at http://www.immd.gov.hk/a report_08-09/eng/ch7/index.htm (Accessed April 1, 2012).

ITBB (1998) Digital 21: Information Technology Strategy, Information Technology and Broadcasting Bureau, Hong Kong.

ITBB (2001) Hong Kong: Connection the World - Digital 21 Strategy, Information Technology and Broadcasting Bureau, Hong Kong.

Kim, C. (2007) 'A cross-national analysis of global e-government', Public Organization Review, Vol. 7, No. 4, pp.317-339.

Knight, L., Harland, C., Telgen, J. and Caldwell, N. (2007) 'E-procurement: a cross-jurisdictional comparison', in Knight, L., Harland, C., Telgen, J., Thai, K.V., Caldwell, G. and McKen, K. (Eds.): Public Procurement: International Case and Commentary, Routledge, London, pp.1-15.

Legislative Council (2006) Legislative Council Panel on Information Technology and Broadcasting: Implementation of Pilot e-Procurement Programme, LC Paper No. CB(1)435/06-07(03), Legislative Council, Hong Kong, Available at http://www.legco.gov.hk/ yr06-07/english/panels/itb/papers/itb1211cb1-435-3-e.pdf (Accessed April 1, 2012).

Legislative Council (2007) Capital Works Reserve Fund Head 710 - Computerisation: Office of the Government Chief Information Officer, New Subhead "Implementation of Pilot e-Procurement Programme" FCR(2006-07)38, Available at http://www.legco.gov.hk/yr0607/english/fc/fc/papers/f06-38e.pdf (Accessed April 1, 2012).

Legislative Council (2009) Legislative Council Panel on Information Technology and Broadcasting: Progress Update on E-Government Development, C Paper No. CB(1)1492/0809(05), Available at http://www.legco.gov.hk/yr08-09/english/panels/itb/papers/itb0511cb11492-6-e.pdf (Accessed April 1, 2012).

Lindskog, H. (2008) 'E-procurement of telecom services for the public sector', Int. J. Knowledge Management Studies, Vol. 2, No. 1, pp.17-28.

Maniatopoulos, G. (2004) 'Enacting e-procurement technologies within UK local authorities', Proceedings of the IADIS International Conference e-Society 2004, IADIS Press, Vol. 2, pp.850-854.

Manoharan, A. and Carrizales, T.J. (2011) 'Technological equity: an international perspective of e-government and societal divides', Electronic Government, An International Journal, Vol. 8, No. 1, pp.73-84.

NASPO (2009) Administrative Fees: Creative Funding for Central Procurement in Difficult Economic Times, The National Association of State Procurement Officials (NASPO). Available at http://www.naspo.org/documents/NASPO_White_Paper_Administrative_Fees Final_090909.pdf (Accessed April 1, 2012).

OGCIO (2007) 2008 Digital 21 Strategy: Continuing to Build our Strengths through Technology across the Community, Office of the Government Chief Information Officer, Hong Kong.

OGCIO (2009) Newsletter for Suppliers: September 2009, Office of the Government Chief Information Officer, Hong Kong, Available at http://www.gov.hk/en/theme/eprocurement/ downloads/newsletter/Supplier_Newsletter_English_Sep_2009_issue.pdf (Accessed April 1, 2012).

OGCIO (2010a) 電子採購試點計劃 [PowerPoint Slides], Office of the Government Chief Information Officer, Hong Kong, Available at http://www.eprocurement.gov.hk/downloads/ PPT/e-Pro_PPT_eSubmission_Chi_v16.pps (Accessed April 1, 2012).

OGCIO (2010b) Supplier-Portal of the E-procurement Pilot Programme, Office of the Government Chief Information Officer, Hong Kong, Available at http://www.eprocurement.gov.hk/en (Accessed April 1, 2012). 
OGCIO (2010c) e-Procurement Pilot Programme: FAQ, Office of the Government Chief Information Officer, Hong Kong, Available at http://www.eprocurement.gov.hk/en/ faqs/index.htm (Accessed April 1, 2012).

OGCIO (2010d) Newsletter for Suppliers: March 2010, Office of the Government Chief Information Officer, Hong Kong, Available at http://www.gov.hk/en/theme/ eprocurement/downloads/newsletter/Newsletter_Suppliers_30Mar_2010.pdf (Accessed April 1, 2012).

OGCIO (2011) IT Sourcing and Contracting, Office of the Government Chief Information Officer, Hong Kong, Available at http://www.ogcio.gov.hk/en/business/business_window/ it_sourcing.htm (Accessed April 1, 2012).

Padhi, S.S. and Mohapatra, P.K.J. (2011) 'Information technology readiness index for adoption of e-procurement', Electronic Government, An International Journal, Vol. 8, No. 1, pp.20-39.

Panayiotou, N.A., Gayialis, S.P. and Tatsiopoulos, I.P. (2004) 'An e-procurement system for governmental purchasing', International Journal of Production Economics, Vol. 90, No. 1, pp.79-102.

PEPPOL (2008) About Peppol, Pan-European Public Procurement Online, Available at http://www.peppol.eu/About_PEPPOL (Accessed April 1, 2012).

Schoenherr, T. and Tummala, W.M.R. (2007) 'Electronic procurement: a structured literature review and directions for future research', Int. J. Procurement Management, Vol. 1, No. 1, pp.8-37.

Trauth, T. (2001) 'E-procurement und e-marketplaces - new trends in B2B e-commerce', e \& i Elektrotechnik und Informationstechnik, Vol. 118, No. 5, pp.253-261.

Ulstrup, L. (2001) The Case for Federal eProcurement Translating Private Sector Benefits to the Federal Government, American Management Systems, Available at http://www.netcaucus. org/books/egov2001/pdf/The_Case.pdf (Accessed April 1, 2012).

World Bank (2003) Electronic Government Procurement (e-GP): World Bank Draft Strategy, Available at http://siteresources.worldbank.org/INTPROCUREMENT/Resources/eGPStrategy fortheWBword.doc (Accessed April 1, 2012).

Zarnekow, R., Brenner, W. and Eyholzer, K. (2002) 'E-Procurement in deröffentlichen Beschaffung', HMD Praxis der Wirtschaftsinformatik, Vol. 226, No. 39, pp.44-58. 